\title{
ADAPTIVE PHYSIOLOGICAL RESPONSE TO LOAD TIME STRESS DURING TRANSPORTATION OF CATTLEIN NIGERIA
}

\author{
RESPUESTA FISIOLÓGICA DE ADAPTACIÓN DE BOVINOS AL ESTRÉS \\ DURANTE EL TRANSPORTE DE LARGA DURACIÓN EN NIGERIA
}

\author{
Eniolorunda, O.O., O.E. Fashina and O.O. Aro
}

Department of Animal Production. College of Agricultural Sciences. Olabisi Onabanjo University. Yewa Campus. Ayetoro. Ogun State Nigeria.

\section{Additional KeYWORDS}

Adaptive physiology. White Fulani. Sokoto Gudali.

\section{SUMMARY}

The effect of local time stress on changes in rectal temperature $(R T)$, respiratory rate $(R R)$ heart rate $(H R)$ and pulse rate $(P R)$ were evaluated in mature White Fulani (WF) and Sokoto Gudali (SG) breeds of cattle in a $2 \times 5$ factorial experiment. A total of 24 bulls (12 of each breed) were subjected to loading, unloading and holding procedures. All adaptive physiological measurements in the experimental animals were taken before loading (pre-load) and immediately after loading (post-load). These variables were again recorded in holding lairage at 0,6 and $12 \mathrm{hr}$ after transportation to assess the time-cause of stress response. Respiratory, heart and pulse rates were higher $(p<0.05)$ while rectal temperature was insignificantly higher $(p>0.05)$ in Sokoto Gudali than in White Fulani bulls (104.03 vs. 100.63 beats $\mathrm{min} ; 102.87$ vs. 99.17 beats/min; 103.27 vs. 99.37 beats $/ \mathrm{min}$ and $39.20 \mathrm{vs} .39 .07^{\circ} \mathrm{C}$ ) when subjected to load time stress (procedures). All the variables measured showed distinct significant differences with the minimum measurement recorded at $12 \mathrm{hr}$ holdtime period while the maximum values were attained at the post-load time period for RR, HR and PR and at un-load time period for the RT. The higher magnitude of increase in RR in the animals during the period of loading therefore suggests that these animals were more stressed at this period than at any other loadtime period. The interaction between breed and loadtime period indicates that the magnitude of increase in RR was higher $(p<0.05)$ in White Fulani than in Sokoto Gudali cattle. The lower magnitude of increase in RR in the

Recibido: 9-3-07. Aceptado: 21-2-08.

\section{PaLABRAS CLAVE ADICIONALES}

Fisiología adaptativa. White Fulani. Sokoto Gudali.

Sokoto Gudali cattle again suggests that this breed was less stressed than the White Fulani cattle during the strenuous loadtime stress since adverse effects of stress factors due to loading, unloading and holding of animals is inevitable during and after transportation of animals. It is therefore pertinent to minimize simultaneous actions of these stress factors in order to reduce economic losses and stress to animals due to loadtime stress.

\section{RESUMEN}

Los efectos del estrés de transporte sobre la temperatura rectal $(R T)$, tasa respiratoria (RR), frecuencia cardiaca (HR) y frecuencia de pulso (PR) fueron evaluados en animales maduros de las razas bovinas White Fulani (WF) y Sokoto Gudali (SG) en un experimento factorial $2 \times 5$. Un total de 24 toros (12 de cada raza) fueron sometidos al estrés derivado de los procedimientos de carga, descarga y alojamiento. Todas las medidas de fisiología adaptativa en los animales experimentales, fueron tomadas antes de la carga e inmediatamente después de la carga. Esas variables fueron registradas de nuevo en la zona de alojamiento 0,6 y 12 horas después del transporte, para establecer el tiempo de respuesta al estrés. La (RT) tasa respiratoria, frecuencia cardiaca $(H R)$ y frecuencia de pulso (PR) fueron más elevadas $(p<0,05)$ mientras que la temperatura rectal fue insignificantemente mayor en los toros Sokoto Gudali (SG) que en los White Fulani (WF) (104,03 vs. 100,63 latidos/min; 102,87 vs. 99,17 


\section{ENIOLORUNDA, FASHINA AND ARO}

latidos/min; 103,27 vs. 99,37 latidos/min y 39,20 vs. $39,07^{\circ} \mathrm{C}$ ) cuando fueron sometidos al estrés de carga. Todas las variables controladas mostraron distintas diferencias significativas con los valores mínimos de la medida, obtenida a las 12 horas del periodo de alojamiento. Por otro lado, los valores máximos fueron alcanzados en el periodo posterior a la carga para RR, HR y PR y en el periodo de descarga para RT. La mayor magnitud de incremento de RR en los animales durante el periodo de carga sugiere que los animales estaban más estresados en este periodo que en otro momento de la carga. La interacción entre raza y tiempo de carga indica que la magnitud del incremento en RR fue mayor $(p<0,05)$ en la raza White Fulani que en la Sokoto Gudali. La inferior magnitud de incremento de RR en la raza Sokoto Gudali, sugiere de nuevo, que estos animales estaban menos estresados que los de la raza White Fulani durante los momentos en los que se produce el estrés de la carga. Puesto que los efectos adversos del estrés durante la carga, descarga y alojamiento de los animales son inevitables, es pertinente minimizar las acciones simultáneas de esos factores de estrés para minimizar, de este modo, las pérdidas económicas y el estrés de los animales por este concepto.

\section{INTRODUCTION}

The demand for livestock to be marketed outside places where they are produced have necessitated animal transport all over the world. In Nigeria, most of the cattle are mostly transported by road from the neighbouring countries (Cameroon, Chad, Mali and Niger) and the northern part of the country to the southern part where they are marketed and slaughtered for meat. During road transport however, animals are inevitably exposed to handling and loading, transportation, unloading and confinement procedures which, often result in severe stress. Loading of animals reared predominantly in Nigeria or in the neighbouring countries under the free grazing system into a vehicle has been reported to be an unusual exercise (Ayo and Oladele, 1996). This constitutes a break in the dynamic stereotyping of the animal, often accompanied by excessive noise, chasing of animals with sticks, long standing while waiting for the vehicle or its departure, pushing and kicking of the animals. Factors such as poor ramp design, narrow doors, unnecessary projections, improper positioning of loading spots have also been reported to contribute to injuries, stress and suffering in food animals. (Scott, 1986 and Nikitchenco et al., 1988). Furthermore, the combined effect of these stressors have been reported to impair the homeostatic control mechanism of the animal; thus resulting in metabolic shift and altered bodily physiological measurements (Kent and Ewbank, 1986; Phyaschenko and Sidorov, 1987; Nikitchenko et al., 1988 and Barrio etal., 1993).

The management of cattle during preslaughter transportation and handling could influence both profitability and animal welfare. Severe pre-slaughter stress has been reported to adversely affect health status and meat quality in livestock (Warner et al., 1986; Apple et al., 1995; Von Borell, 2001); and poultry (Kannan et al., 1998). Transport stress therefore results in dysfunction of the pituitary gland and adrenal cortex, thyroid gland and changes in the cellular and biochemical components of the blood as well as other bodily measurements (Plyaschenko and Sidorov, 1987). Meanwhile, researchers have used adaptive physiological indicators to assess stress levels in animals. Rectal temperature, respiratory, heart and pulse rates have been used as reliable indicators of short time physical stress in animals (Plyaschenko and Sidorov, 1987; Verstergen, 1987; Lu, 1989; Becker et al., 1989; Oladimeji et al., 1996 and Ayo et al., 1998). Adaptive physiological response to other stress factors have been studied in livestock species but the data on cattle subjected to loadtime stress are very limited. This study was therefore designed to evaluate the stress response to loadtime procedures during road transportation of cattle.

Archivos de zootecnia vol. 58, núm. 222, p. 224. 


\section{RESPONSE TO LOADTIME STRESS DURING TRANSPORTATION OF CATTLE}

\section{MATERIAL AND METHODS}

A total of 24 matured bulls, about 3-7 years old, consisting of 12 White Fulani (WF) weighing $258.86 \pm 20.25 \mathrm{~kg}$ and 12 Sokoto Gudali (SG) weighing $308.58 \pm 16.70$ $\mathrm{kg}$ were used in this study. The animals were horned and were raised for meat purpose. They were generally raised on free range pasture, groundnut and cowpea hays with sorghum and millet grain supplements, water was also offered to the animals ad libitum. The animals were kept in the open field prior to transportation without shelter except for trees that provided shade for the animals and some huts used for keeping grain supplements and stockers personal belongings. This experiment was conducted during the hot humid rainy season (June) simulating commercial situations in Nigeria. Care was also taken not to include any animal showing signs of ill health.

The animals were transported from Gwobawa in Sokoto State to Ojoo in Lagos State in an open trailer pulled by an Iveco truck. The trailer has a total cabin space of $12.12 \times 2.4 \times 2.4 \mathrm{~m}^{3}$ with a metal scarfold attached to the top. Shade was provided for the animals when necessary by mats made from cured straws spread over the scarfold. Thermometers and hygrometers were also attached to the scarfold at two different locations to measure the average ambient temperature $\left({ }^{\circ} \mathrm{C}\right)$ and relative humidity $(\%)$ at the loading and unloading spots. Prior to loading procedures the transporting trailer was packed at a loading spot 20 meters from a smaller enclosure (measurement area). Meanwhile the animals were moved into the smaller enclosure an hour before the commencement of physiological measurements weighing and loading into the trailer. Each animal was gently apprehended (to minimize excitement due to handling) in order to measure the variables before loading (pre loadtime). The handling and loading procedures of animals into the trailer started at $07.00 \mathrm{hrs}$ and was completed within $2 \frac{1}{2}$ hrs. they were loaded into the trailer by hired local stock handlers who used rope to tie the horns, neck or forelimbs of each animal. Clubs and whips were also used to kick, push and pull the animals individually with commanding noise into the vehicle through the loading ramp that was inclined at about $30^{\circ}$. The stocking density per animal was about $3.09 \mathrm{~m}^{2}$ irrespective of the slope, size and the horn status of the animals. After loading, adaptive physiological functions of each animal were again measured (postload) to evaluate the stress response due to loading stress.

The trailer started the journey thereafter and travelled from Gwobawa in Sokoto State to Ojoo in Lagos State covering a distance of $1024 \mathrm{~km}$ within $42 \mathrm{hrs}$. After transportation, animals were held in an open lairage for 12 hrs without food but with ad libitum access to water. During holdtime period, all measurements on the animals were taken at $0 \mathrm{hr}$ (off loadtime), 6 and $12 \mathrm{hrs}$ after transportation (off loadtime periods) to access time cause effect on stress response by the animals. Ambient temperature $\left({ }^{\circ} \mathrm{C}\right)$, relative humidity (\%) and time at Gwobawa, Sokoto State on the day of departure and at Ojoo in Lagos State on the day of arrival were recorded using a thermometer, hygrometer and a clock respectively. Respiratory rate (RR) was measured using a stethoscope. Heart rate (HR) was also measured with the aid of a stethoscope on the $4^{\text {th }}$ half intercostal space. Pulse rate (PR) was determined at the root of the tail with the aid of the hand. rectal temperature $\left(\mathrm{RT}^{\circ} \mathrm{C}\right)$ was taken using a digital thermometer.

The data were subjected to analysis of variance using Statistical Analysis System (SAS, 1993). The mean effect in the model were breed (White Fulani vs Sokoto Gudali), treatment (preload, postload, offload or $0 \mathrm{hr}$ holdtime, $6 \mathrm{hr}$ holdtime and $12 \mathrm{hr}$ holdtime) and the breed $x$ treatment interactions. Least square means were used to evaluate the breed $\mathrm{x}$ treatment interaction effects and the 


\section{ENIOLORUNDA, FASHINA AND ARO}

Table I. Mean effect of loadtime stress on the adaptive physiological measurements in White Fulani and Sokoto Gudali breeds of cattle. (Efecto medio del estrés por carga sobre los valores de adaptación fisiológica en las razas bovinas White Fulani and Sokoto Gudali).

\begin{tabular}{lccr}
\hline \multirow{2}{*}{ Measurement } & \multicolumn{2}{c}{ Breeds of cattle } & \\
& White Fulani & Sokoto Gudali & SEM \\
\hline Rectal temperature $\left({ }^{\circ} \mathrm{C}\right)$ & 39.07 & 39.20 & 0.23 \\
Respiration rate $(\mathrm{breath} / \mathrm{min})$ & $100.63^{\mathrm{b}}$ & $104.03^{\mathrm{a}}$ & 2.26 \\
Heart rate (beats $/ \mathrm{min})$ & $99.17^{\mathrm{b}}$ & $102.87^{\mathrm{a}}$ & 2.77 \\
Pulse rate (beats $/ \mathrm{min})$ & $99.37^{\mathrm{b}}$ & $103.27^{\mathrm{a}}$ & 2.83 \\
\hline
\end{tabular}

abbetween breeds of cattle, means followed by different superscripts differ significantly $(p<0.05)$.

difference between means at a probability $<0.05$ was considered significant (Ott, 1993).

\section{RESULTS}

The ambient temperature and relative humidity during loading procedures and at departure from Gwobawa in Sokoto State (Load spot) by 11.00 am were $33^{\circ} \mathrm{C}$ and $46 \%$ respectively. Also the temperature and relative humidity on arrival at Ojoo in Lagos State by 5.00 am on the third day were $21^{\circ} \mathrm{C}$ and $80 \%$. Later in the day however, corresponding values were $39^{\circ} \mathrm{C}$ and $36^{\circ} \mathrm{C}$ for ambient temperature and $29 \%$ and $39 \%$ relative humidity at $6 \mathrm{hr}$ and $12 \mathrm{hr}$ holdtime periods respectively.

The main effect of loadtime stress on the changes in the rectal temperature $\left(\mathrm{RT}^{\circ} \mathrm{C}\right)$, respiratory rate (RR), heart rate (HR) and pulse rate $(\mathrm{PR})$ in breeds of cattle is presented in table I. It was observed that Sokoto Gudali (SG) bulls had higher $(\mathrm{p}<0.05) \mathrm{RR}, \mathrm{HR}$ and PR than White Fulani (WF) bulls (104.03 vs 100.63 SEM 2.26 breadths/min; 102.87 vs 99.17 SEM 2.77 beats/min and $103.27 \mathrm{vs}$ 99.37 SEM 2.83 beats/min respectively) when subjected to loadtime stress during transportation. However the main effect of loadtime stress did not cause any appreciable difference $(\mathrm{p}>0.05)$ in RT between both breeds of cattle.

The effect of loadtime period on the changes in the RT, RR, HR and PR is represented in table II. There were distinct significant differences $(p<0.05)$ in the adaptive physiological variables across the loadtime periods. Respiratory, Heart and Pulse Rates increased $(\mathrm{p}<0.05)$ when the animals were either subjected to loading procedures (post-load time periods) or subjected to un-loading procedures (un-

Table II. Effect of loadtime (period) stress on the adaptive physiological measurements in cattle. (Efecto del estrés por carga sobre los valores de fisiología adaptativa).

\begin{tabular}{lcccccc}
\hline Measurement & $\begin{array}{c}\text { Pre-load } \\
\text { time }\end{array}$ & $\begin{array}{c}\text { Post-load } \\
\text { time }\end{array}$ & $\begin{array}{c}\text { Un-hold } \\
\text { time }\end{array}$ & $\begin{array}{c}6 \text { hr hold } \\
\text { time }\end{array}$ & $\begin{array}{c}12 \text { hr hold } \\
\text { time }\end{array}$ & SEM \\
\hline Rectal temperature $\left({ }^{\circ} \mathrm{C}\right)$ & $38.75^{\mathrm{c}}$ & $39.73^{\mathrm{a}}$ & $39.63^{\mathrm{b}}$ & $39.05^{\mathrm{b}}$ & $38.53^{\mathrm{c}}$ & 0.40 \\
Respiration rate $($ breath/min) & $82.17^{\mathrm{d}}$ & $130.33^{\mathrm{a}}$ & $120.67^{\mathrm{b}}$ & $97.58^{\mathrm{c}}$ & $80.92^{\mathrm{d}}$ & 3.58 \\
Heart rate (beats/min) & $89.75^{\mathrm{d}}$ & $119.92^{\mathrm{a}}$ & $111.58^{\mathrm{b}}$ & $98.72^{\mathrm{c}}$ & $88.17^{\mathrm{d}}$ & 2.62 \\
Pulse rate (beats/min) & $89.50^{\mathrm{d}}$ & $120.83^{\mathrm{a}}$ & $111.92^{\mathrm{b}}$ & $95.92^{\mathrm{c}}$ & $88.42^{\mathrm{d}}$ & 2.65
\end{tabular}

abcd Within loadtime, means followed by different superscripts differ significantly $(p<0.05)$.

Archivos de zootecnia vol. 58, núm. 222, p. 226. 


\section{RESPONSE TO LOADTIME STRESS DURING TRANSPORTATION OF CATTLE}

load time period) with post-load time measurements eliciting higher $(\mathrm{p}<0.05)$ values (130.33 vs 120.67 SEM 3.58 breadths/ min; 119.92 vs 111.58 SEM 2.62 beats/minand 120.83 vs 111.92 SEM 2.65 beats $/ \mathrm{min}$ ). However, the variables began decreasing $(\mathrm{p}<0.05)$ within $6 \mathrm{hr}$ of holdtime period (after transportation and unloading) to reach corresponding pre-load time measurements at $12 \mathrm{hr}$ holdtime period ( $82.17 \mathrm{vs} 80.92$ SEM 3.58 breadths $/ \mathrm{min} ; 89.75$ vs 88.17 SEM 2.62 beats/min and $89.50 \mathrm{vs} 88.42$ SEM 2.65 beats/ min). Rectal temperature also increased $(p<0.05)$ at post-load time period, peaked at un-load time period ( $0 \mathrm{hr}$ holdtime period) and decreased thereafter reaching pre-load time value at $12 \mathrm{hr}$ holdtime period.

Effect of the interaction between breed and treatment on the changes in adaptive physiological measurement is presented in table III. The least square means of breed $x$ treatment interaction was significant $(p<0.05)$ for all the variables measured. The basal RR and HR were higher $(\mathrm{p}<0.05)$ in SG ( 85.00 breaths $/ \mathrm{min}$ and 91.17 beats $/ \mathrm{min}$ ) than
WF $(79.22$ breaths/min and 88.17 beats/min) bulls at pre-load time period and loadtime stress increased $(\mathrm{p}<0.05)$ the $R R$ to 130.33 breaths $\min ^{-1}$ and the HR to 117.83 beats/ min in SG and to 130.33 breaths min and 114.50 beats min in WF bull. However, the basal PR and RT were insignificantly higher $(\mathrm{p}>0.05)$ in $\mathrm{SG}\left(91.67\right.$ beats $/ \mathrm{min}$ and $38.90^{\circ} \mathrm{C}$ ) than WF $\left(89.33\right.$ beats/min and $38.60^{\circ} \mathrm{C}$ bull at pre loadtime period but loading stress increased $(p<0.05)$ the PR to 122.67 beats/ min and the RT to $39.03^{\circ} \mathrm{C}$ in SG and to 119.00 beats/min and $40.22^{\circ} \mathrm{C}$ in WF cattle. In addition, the magnitude of the increases were higher $(\mathrm{p}<0.05)$ for RR $(51.11$ breaths/ $\min )$ and RT $\left(1.62^{\circ} \mathrm{C}\right)$ in WF than in SG (45.33) breaths and $1.62^{\circ} \mathrm{C}$ ) bulls. Heart and pulse rates increased with loading to about the same magnitude in both breeds of cattle. Also stress increased RR to 119.17 breaths/ $\mathrm{min}, \mathrm{HR}$ to 108.67 beats/min; PR to 108.83 beats/min and RT to $39.77^{\circ} \mathrm{C}$ in WF and RR to $122.17 \mathrm{breaths} / \mathrm{min}$; PR to 115.00 beats/ min and $39.70^{\circ} \mathrm{C}$ in SG bulls. However, the magnitude of increases were lower in RR

Table III. Least square means of adaptive physiological measurements in White Fulani and Sokoto Gudali breeds of cattle when subjected to load, unload and holdtime stress. (Medias mínimas cuadráticas en las razas bovinas White Fulani y Sokoto Gudali, cuando son sometidas a estrés por carga, descarga y alojamiento).

\begin{tabular}{|c|c|c|c|c|c|c|}
\hline & \multicolumn{5}{|c|}{ Load time periods } & \multirow[b]{2}{*}{ SEM } \\
\hline & Preload & Post-load & Unload & $6 \mathrm{hr}$ Holdtir & hr Holdtime & \\
\hline \multicolumn{7}{|c|}{ Rectal temperature $\left({ }^{\circ} \mathrm{C}\right)$} \\
\hline White Fulani & 38.60 & $40.22^{a}$ & 39.77 & 38.98 & 38.84 & \\
\hline Sokoto Gudali & 38.90 & $39.03^{b}$ & 39.70 & 39.12 & 38.62 & 0.34 \\
\hline \multicolumn{7}{|c|}{ Respiration rate (breath min) } \\
\hline White Fulani & $79.22^{b}$ & 130.33 & $119.17^{\mathrm{b}}$ & 99.67 & $78.67^{b}$ & \\
\hline Sokoto Gudali & $85.00^{a}$ & 130.33 & $122.17^{\mathrm{a}}$ & 99.50 & $83.17^{a}$ & 2.92 \\
\hline \multicolumn{7}{|c|}{ Heart rate (beats/min) } \\
\hline White Fulani & $88.17^{\mathrm{b}}$ & $114.50^{\mathrm{b}}$ & $108.67^{b}$ & 94.83 & $86.33^{b}$ & \\
\hline Sokoto Gudali & $91.17^{a}$ & $117.83^{a}$ & $114.50^{\mathrm{a}}$ & 96.67 & $90.00^{a}$ & 2.72 \\
\hline \multicolumn{7}{|c|}{ Pulse rate (beats/min) } \\
\hline White Fulani & $87.33^{\mathrm{b}}$ & $119.00^{\mathrm{b}}$ & $108.83^{b}$ & 95.17 & 89.50 & \\
\hline Sokoto Gudali & $91.67^{a}$ & $122.67^{a}$ & $115.00^{\mathrm{a}}$ & 96.67 & 90.33 & 2.78 \\
\hline
\end{tabular}

abWithin breeds of cattle, means followed by different superscripts differ significantly $(p<0.05)$. 


\section{ENIOLORUNDA, FASHINA AND ARO}

(37.17 breaths) and RT $\left(0.80^{\circ} \mathrm{C}\right)$ but higher in HR ( 23.33 beats) and PR ( 23.33 beats for SG than for those for $\mathrm{WF}\left(39.95\right.$ breaths, $1.17^{\circ} \mathrm{C}$, 20.50 beats and 19.50 beats respectively bulls.

All adaptive physiological functions decreased $(\mathrm{p}<0.05)$ at $6 \mathrm{hr}$ loadtime period with the magnitude of the decrease lower for WF than for SG cattle (19.50 vs 22.67 breaths; 8.84 vs 17.83 beats and 13.60 vs 18.33 beats respectively). Bodily functions further decreased in both breeds of cattle at $12 \mathrm{hr}$ holdtime period with the magnitude of the decrease higher for RR and HR but lower for $P R$ and RT in WF than in SG (21.00 vs 16.33 breaths 13.50 vs 6.67 beats; 5.67 vs 6.34 beats and 0.14 vs $0.50^{\circ} \mathrm{C}$ ) cattle.

\section{DISCUSSION}

Loading, transportation, unloading and holding stress have been reported to cause drastic changes in the bodily functions of animals as these stressors over exert their body systems (Kent and Ewbank, 1983; Scott, 1986; Becker et al., 1989; Barrio et al.,
1993 and Ayo et al., 1998). The varied intensity of animal response to loadtime stress in this study was probably aggravated by the magnitude of the physical, psychic and vastibular exertion primarily due to chasing of Animals with stick, excessive noise, pushing and kicking, long standing while waiting for the vehicle or its departure, poor ramp designs, climatic factors, feeding level, distance and duration of the transport. Plyaschenko and Sidorov (1987) and Ayo et al. (1998) reported that the combined effect of these stressors on the animal impairs its homeostatic control mechanism resulting in metabolic shift and change in adaptive physiological measurement. These measurements are rectal temperature, respiration, heart and pulse rates. Similar changes in the RT, RR, HR and PR were obtained by Plyascenko et al. (1987); Nikitchenko et al. (1988); Lefarcheur et al.,(1991); Barrio et al. (1993); Ayo et al. (1998) and Von Borell (2001); in food animals under stressful transport conditions.

The higher magnitude of increase in RT, RR, HR and PR at post-load time period

Table IV. Magnitude of the difference in $R T, R R, H R$ and $P R$ when White Fulani and Sokoto Gudali cattle were subjected to loadtime stress. (Magnitud de la diferencia en RT, RR, HR y PR cuando los bovinos White Fulani y Sokoto Gudali son sometidos a estrés por tiempo de carga).

\begin{tabular}{lcccc}
\hline & Loading & \multicolumn{3}{c}{ Holding } \\
& & $0 \mathrm{hr}$ & $6 \mathrm{hr}$ & $12 \mathrm{hr}$ \\
\hline Rectal temperature $\left({ }^{\circ} \mathrm{C}\right)$ & & & \\
$\quad$ White Fulani & +1.62 & -0.45 & -0.79 & -0.14 \\
$\quad$ Sokoto Gudali & +0.13 & +0.67 & -0.58 & -0.50 \\
Respiration rate (breath min) & & & & -19.00 \\
$\quad$ White Fulani & +51.11 & -11.16 & -19.50 & -21.00 \\
$\quad$ Sokoto Gudali & +45.33 & -8.16 & -22.67 & -16.33 \\
Heart rate (beats/min) & & & -8.84 & -18.50 \\
$\quad$ White Fulani & +26.33 & -5.83 & -17.83 & -6.67 \\
$\quad$ Sokoto Gudali & +26.66 & -3.33 & -13.66 & -5.67 \\
Pulse rate (beats/min) & & -10.17 & -18.33 & -6.34 \\
$\quad$ White Fulani & +31.67 & -7.67 & & \\
$\quad$ Sokoto Gudali & +31.00 & &
\end{tabular}

Archivos de zootecnia vol. 58, núm. 222, p. 228. 


\section{RESPONSE TO LOADTIME STRESS DURING TRANSPORTATION OF CATTLE}

indicate that the loading stress (procedure) over exert the animal's body systems more than at any other loadtime periods. The observed increase in RT either at post-load time or at un-load time period suggest that these animals were generating more body heat primarily due to prominent exertion resulting into metabolic shift (Kent and Ewbank, 1983; Nikitchenko et al., 1988 and Becker et al., 1989) during these periods. Meanwhile, the increase in RR observed during the same period might probably be due to a mechanism for the elimination of as much heat as possible by the animal. The higher HR and PR observed in this study might be as a result of heat loss through enhanced respiratory vapourisation and greater energy requirement associated with the physical activity during loading and unload time stress (procedures). Similar elevated body temperature, respiration and pulse rates were obtained by Verstegen (1987) in pigs, and Lu (1989) in goats under stressful vehicle transport conditions. The clearly manifested excitation and apprehension in the first stage of transport stress (handling and loading procedures was probably replaced gradually by strong depression on arrival (Verstegen, 1987). Thus the rectal temperature, respiration, heart and pulse rates dropped sharply (table IV), indicative of low metabolic rate, altered bodily physiological parameters and weak host defensive mechanism (Plyaschenko and Sidorov, 1987) and (Von Borell, 2001).

In addition to stress due to loadtime itself, animals were exposed to changes in temperature, relative humidity, feeling of level, distance and duration of transport, Cole et al. (1987) and Lefaucheur et al. (1991) therefore reported that these factors have direct negative effects on optimum production by reducing heat production and the energy available for maintenance and production. They reported further that the combined effect of these extraneous factors weakens significantly the body resistance to diseases by depressing cellular and humeral immunity of the animal.

\section{CONCLUSION}

The very process of loading of animals into or un-loading of animals out of a vehicle is an unusual exercise which is very stressful. The process was however accompanied by some extraneous factors which might have either singly or in combination triggered off physiological exertion, thus resulting into elevated adaptive physiological measurements. The higher magnitude of increase in RT, Respiration, Heart and pulse rates at the post-load time period shows that the animals were more stressed than at any other period. The interaction between breed and loadtime period indicate that White Fulani cattle was more adversely affected than Sokoto Gudali cattle (table IV) when subjected to loading and un-loading procedures. In addition, the lower magnitude of increase in respiration rate in Sokoto Gudali cattle again suggests that the breed was less stressed than the White Fulani cattle during the strenuous loading and holding procedures. In addition, the effect of stress due to transportation and un-load time procedures in this study persisted for approximately $12 \mathrm{hrs}$ in both breeds of cattle.

Since adverse effect of stress factors due to loading and un-loading of animals during transportation is inevitable, it is therefore pertinent to drastically reduce simultaneously action of many stress factors in order to minimize economic loses and stress. Specialized vehicle for transportation of animals, proper positioning of loading spots, avoiding unnecessary projections to vehicles, conducive holding facilities and keeping to the laws and regulations guiding animal transport are very important in alleviating animal stress and suffering during loading, unloading and holding procedures. 


\section{ENIOLORUNDA, FASHINA AND ARO}

\section{REFERENCES}

Apple, J.K., M.E. Dikeman, J.E. Minton, R.M. McMurphy, M.R. Fedde, D.E Leith and J.A. Unruh. 1995. Effects of restraint and isolation stress and epidual blockado on endocrine and blood metabolic status, muscle glycogen metabolism, and incidence of dark-cutting Longissimus muscle of sheep. J. Anim. Sci., 73: 2295-2307.

Ayo, J.O. and S.B. Oladele. 1996. Road transport stress in food animals in Nigeria. A review. Nig. Vet. J., Special edition, 1: 49-57.

Ayo, J.O, S.B. Oladele, A. Fayomi, S.D. Jumbo and J.O. Hambolu. 1998. Body temperature, respiration and heart rates in the Red Sokoto goat during harmattan season. Bull. Anim. Health Prod. Africa, 46: 161-166

Barrio, A.S., J.W. Schrama, W. van der Hel, H.M. Beltman and M.W.A. Verstegen. 1993. Energy metabolism of growing pigs after transportation, regrouping and exposure to new housing conditions as affected by feeding level. $J$. Anim. Sci., 71: 1754-1760.

Becker, B.A.I., H.F. Mayes, G.L. Hahn, J.A. Nienabar, G.W. Jeis, M.E. Anderson, H.I. Hegmann and H.B Hendrick. 1989. Effect of fasting and transportation on various physiological parameters and meat quality of slaughtered hogs. J. Anim. Sci., 69: 324-340

Cole, N.A., W.A. Phillips and D.P. Hutchson. 1987. Effect of prefast on transport calves. J. Anim. Sci., 63: 1015-1020.

Kannan, G., J.L. Heath, C.J. Wabeck, S.L. Owens and J.A. Mench. 1998. Elevated plasma corticosterone concentrations influence on the onset of rigor mortis and meat colour in broilers. Poult. Sci., 77: 322-328.

Kent, J.K. and R. Ewbank. 1983. The effect of road transportation on the blood constituents and behaviour of calves. I: Six months old. Brit. Vet. J., 139: 228-235.

Kent, J.K. and R. Ewbank. 1986. The effect of road transportation on the blood constituents and the behaviour of calves, in one to three months old. Brit. Vet. J., 142: 131-140.
Lefaucheur, L., J. Le Dividich, J. Mourol, G. Monir P. Ecolan and D. Kranse. 1991. Influence of environmental temperature on growth, muscle and adipose tissue metabolism and meat quality in swine. J. Anim. Sci., 69: 2844-2851.

Lu, C.D. 1989. Effect of heat stress on goat production. Small Ruminant Res., 2: 151-162.

Nikitchenko, I.N, S.I. Plyaschenko and A.C. Zenkou. 1988. Adaptation, stresses and productivity of farm animals. Urajai Publishing House. Minskscott (In Russian).

Oladimeji, O., A Osinowo J.P. Alawa and J.O. Hambolu. 1996. Seasonal and diurnal changes in respiration rate, pulse rate and rectal transportation in Yankassa sheep of different age groups and sexes in the sub-humid Tropic. J. Anim. Prod. Res., 16: 45-48.

Ott, R.L. 1993. Analysis of Variance in some standard experimental designs. In: An introduction to statistical methods and data analysis. Duxbury Press. Belmont, CA, p. 842-928.

Plyaschenko, S.I and V.T. Sidorov. 1987. Stresses in farm animal. Agropromizdat. Moscow. 192 p. (in Russian).

SAS. 1993. SAS/STAT User's Guide, vol. 2, Version 6. Statistical analysis system. SAS Inst. Inc. Cary, NC.

Scott, W.N. 1986. The transport of L/S in the care and management of farm animals. Published by Churchill Livingstone. Kidlington. UK. p. 216221.

Verstegen, M.V.A. 1987. Swine. In: H.D. Johnson (ed) Bioclimatology and adaptation of L/S. Elsevier Science Publishers. Amsterdam. The Netherlands. $245 \mathrm{p}$.

Von Borell, E.H. 2001. The biology of stress and its application to livestock housing and transportation assessment I. J. Anim. Sci., 79 (e. supply): E267-E277.

Warner, R.D., G.A. Eldridge, J.L. Barnett, C.G Haplin and D.J Cahill. 1986. Effect of frosting and cold stress on dark-cutting and bruising in cattle. P. Aust. Soc. Anim. Prod., 16: 383-386. 